\title{
A CROSS NATIONAL STUDY OF GOLF TOURISTS' SATISFACTION
}

\author{
Miguel Moital \\ Senior Lecturer in Events Management \\ Bournemouth University \\ School of Tourism \\ United Kingdom \\ mmoital@bournemouth.ac.uk \\ Nuno Ricardo Dias \\ Lecturer in Tourism \\ Estoril Higher Institute for Hotel and Tourism Studies \\ Portugal \\ Danielle F. C. Machado \\ Lecturer in Tourism \\ Department of Tourism, Federal University of Juiz de Fora \\ Juiz de Fora, Brazil
}

\begin{abstract}
The purpose of this study was two-fold: firstly, it was to examine the determinants satisfaction levels of golf tourists and secondly to investigate if these vary across golf tourists' country of residence. Using data collected through a survey of golf tourists visiting Lisbon (Portugal), attributes directly related to playing golf as well as more generic destination attributes were examined as potential determinants of golf tourists' satisfaction. The data was analysed in two stages by the means of logistic regression. In stage one, the analysis was based on a representative sample of golf tourists to the region. In the second stage, two separate analyses were undertaken, one examining the satisfaction of Nordic golf tourists and another of British golf tourists (the two main markets for Lisbon). The results indicate that the satisfaction level of golf tourists is influenced by several factors, including those related to perceived quality and value. In addition, the results suggest that satisfaction is influenced by cross-cultural differences. While some determinants were important influences for both the British and the Nordic golfers, other determinants were specific to each country of origin.
\end{abstract}

Keywords: Satisfaction, Golf tourism, Quality, Value, Logistic regression, Cross-cultural studies, Lisbon.

\section{Cite as}

Moital, M, Dias, N. R. and Machado, D. F. C, 2013. A Cross National Study of Golf Tourists' Satisfaction, Journal of Destination Marketing \& Management. 2 (1), 39-45.

\section{INTRODUCTION}

In order to hold a strong competitive position, destinations are required to hold a balanced product portfolio. This involves developing existing products so that weaknesses are overcome, as well as developing new products so as to explore internal strengths and market opportunities. This might involve adopting a diversification strategy, which focuses on new products for new markets. Diversification strategies are usually associated with attempting to attract high value-added tourists in markets that are expected to grow 
(Schmallegger, Taylor, \& Carson, 2011; Boukas \& Ziakas, 2012). Golf tourism has been identified as one such market by many destinations because the golf tourist tends to earn higher levels of income when compared to more established tourist segments, which leads to a higher average spending (MINTEL, 2006). In addition, golf tourism has been regarded as a means of reducing tourism seasonality, notably in destinations which are traditionally dependent on sun \& sea tourism (Garau-Vadell \& Borja-Solé, 2008; Boukas \& Ziakas, 2012).

Portugal is an example of one country where golf tourism has achieved an important status. It is considered as a priority tourism product (Portuguese Tourism Board, 2007). According to the Portuguese government, in 2006 the average spending per day of a golf tourist was approximately $260 €$ (Portuguese Tourism Board, 2007). A more recent study by the Lisbon Tourism Board concluded that golf tourists spent the largest amounts of money among all tourists visiting the Lisbon region (Netconsumo.com, 2011). At the same time, golf tourism has made a very important contribution to reduce the seasonality of destinations like the Lisbon Coast. If the city of Lisbon is removed from the analysis, the remainder of the Lisbon Coast is prone to seasonality since it relies more on the leisure market than on the business market (Lisbon Tourism Board, 2010). As the demand of golf tourism tends to be spread around the year, it provides these destinations with a reliable and attractive segment which fulfills vacant capacity in the low season periods.

With 24 golf courses, accounting for $32 \%$ of golf courses in the country (Portuguese Golf Federation, n.d), the Lisbon region has embraced golf as a strategic tourism product. Although the region maintains a steady growth in the number of rounds since the early 2000 s, the occupancy rate of golf courses is lower than $40 \%$, which indicates a substantial spare capacity of $60 \%$ (Lisbon Tourism Board, $\mathrm{n} / \mathrm{d}$ ). The growth in the number of golf courses over the years has not been accompanied by a growth in demand, with the average price per round decreasing since 2004 (Lisbon Tourism Board, n/d). Destinations whose growth has stalled despite substantial spare capacity face the challenge of increasing demand, either through a higher number of rounds and/or the average price per round. This can be achieved through longer stays, greater levels of re-visitation or new demand. Past research suggests high levels of satisfaction are a critical factor in influencing these outcomes (Yoon \& Uysal, 2005). Therefore, monitoring tourist satisfaction is an important step in implementing strategies aimed at improving the performance of tourist destinations through attempting to influence the levels of tourist satisfaction. This involves not only understanding golf tourists' level of satisfaction, but also those factors that contribute to their satisfaction. Therefore, this paper aims to analyse the determinants of golf tourist satisfaction, with a focus on tourists visiting the Lisbon region.

Enhancing our understanding of golf tourists' satisfaction requires exploring approaches and methodologies not used in previous studies. In this article, logistic regression is posited to be a valuable, yet still largely unused, statistical tool for examining golf (and sport) tourists' satisfaction. A second area of enquiry developed in this paper refers to the extent to which country of origin influences golf tourists' satisfaction. Previous studies within the tourism literature have attempted to examine the influence of culture on satisfaction, but the results have been inconsistent. Given the value of such information to destination marketing and management (Kozak, 2001), it is imperative that cross-cultural differences in golf tourists' satisfaction are examined. 


\section{LITERATURE REVIEW}

\section{Satisfaction, quality and value}

Satisfaction is a major construct in the field of tourism research, with many papers devoted to this topic. This reflects the importance of satisfaction for the management of tourist services, whether whole destinations or specific tourism providers such as hotels, airlines and visitor attractions. Much of this research attempts to examine what influences satisfaction. The assumption behind this focus is that by understanding what determines satisfaction, tourism managers will be in a better position to implement appropriate marketing strategies and tactics that will maximise levels of tourist satisfaction (Petrick, Morais, \& Norman, 2001). The importance of studying satisfaction is enhanced once its consequences are recognised. Not only the level of satisfaction has been shown to be related to intention to return, but it is also indication of word-of-mouth behaviours (Kozak \& Rimmington, 2000). In a context where social media provides a platform for word-of-mouth information to many future travellers (Vermeulen \& Seegers, 2009; Zehrer, Crotts, \& Magnini, 2011), managing satisfaction should be a priority for any tourism manager.

Oliver (1997) defines satisfaction as an evaluation of a consumption event or its constituent parts. The study of satisfaction involves addressing two important issues: how satisfaction judgments are formed and what is evaluated. The first involves understanding the mental heuristics (or processes) used by consumers when evaluating an experience. The disconfirmation of expectations posits that consumers develop fairly specific expectations about the performance of the service, which are then compared to the actual performance (Szymanski \& Henard, 2001). From comparing these two elements, consumers become dissatisfied (when actual performance does not match expectations) or satisfied (when performance is better than expectations). Such relationships assume that consumers have positive expectations about the experience. The disconfirmation of expectations heuristic has been employed in several tourist satisfaction studies (e.g. Baker \& Crompton, 2000; Akama \& Kieti 2003). The performance heuristics emphasises the actual performance element at the expense of expectations (Tse \& Wilton, 1988). This is reflected in the use of scales like 'terrible-delighted' (e.g. Kozak \& Rimmington, 2000) and 'very poor-very good (or excellent)' (e.g. Crompton, 2003; Song, van der Veen, Li, \& Chen, 2012). Other heuristics include equity (Oliver \& Swan, 1989) and social equity (Szymanski \& Henard, 2001), the former reflecting a comparison between tourist inputs (sacrifices) and outputs (benefits), and the latter concerns the tourist's perception of the input-output relationship vis-a-vis other tourists. Apart from notions of value for money (e.g. Williams \& Soutar, 2009) and pricequality relationship (e.g. Song et al., 2012), equity-based heuristics have not gained much traction in tourist satisfaction research.

With regards to the second important area of satisfaction research - what is evaluated -, many determinants have been suggested in the tourism literature. Much of the literature focuses on the notion of value as the key influence on tourist satisfaction. For example, Lee, Petrick and Crompton (2007) focused on perceived functional value, overall value and emotional value, while Williams and Soutar (2009) added the dimensions of social and novelty value. A recent study (Bradley \& Sparks, 2012) offered a longer list of value dimensions, to include elements such as rest and relaxation, financial value, quality value, convenience and status and esteem. Other studies specifically focused on service quality, usually through the Servqual dimensions (e.g. Akama \& Kieti, 2003; Hutchinson, Lai, \& Wang, 2009). Additional perspectives on the determinants of satisfaction include brand equity (Nam, Ekinci, \& Whyatt, 2011), the push/pull theory (Prayag \& Ryan, 2012) and Pine and Gilmore's 4 realms of experience (Oh, Fiore, \& Jeoung, 2007). In this study, both value and service quality were assumed to determine golf tourists' satisfaction, hence both areas are reviewed next. 
According to Baker and Crompton (2000) quality differs from satisfaction in that the former measures a provider's output (how well the provider performs), while the latter measures the tourist's outcome. Delivering high quality services is a critical success factor for tourism destinations and organisations alike, since consumers' perceptions of the quality they receive influences their satisfaction (Knutson, Stevens, \& Patton, 1995). The tourism literature has also found convincing evidence for the positive relationship between perceptions of quality and satisfaction (e.g. Baker and Crompton, 2000). Quality is usually conceptualised from a disconfirmation of expectations perspective (Baker and Crompton, 2000). Much of the literature has focused on the dimensions of service quality. The servqual model (Parasuraman, Zeithaml, \& Berry, 1990), with its 5 quality dimensions, is perhaps the most widely used model. In tourism it has been used in different settings such as such as hotels (Ladhari, 2009), low cost carriers (Kim \& Lee, 2002), destinations (Chand, 2010) and sport tourism (Kouthouris \& Alexandris, 2005). With some minor variations, the five dimensions have been found to be important determinants of tourist satisfaction (Ladhari, 2009).

The perceptions of value have also been recognised as an important influence on overall satisfaction judgements (Chen \& Chen, 2010). Two major perspectives on value have been offered over time. Several authors (e.g. Holbrook, 1999; Woodall, 2003) define value as the benefit associated to the consumption of an object or experience. As Bradley and Sparks (2012) summed up, for these authors value is viewed as "something consumers prize over other things" (p. 191). A different perspective associates value to a comparison between what the consumer receives and what it gives (Zeithaml, 1988). Thus, a major difference between the two perspectives is that the latter emphasises the comparison between the benefits and the sacrifices (Sánchez, Callarisa, Rodríguez, \& Moliner, 2006), while the former notion of value places emphasis on the comparison between the benefits of the different offers. The study of value within the context of tourism services has been the focus of many studies, with these studies showing that value is a multi-dimensional concept. For example, Petrick (2002a) identified five dimensions of perceived value: (1) quality; (2) emotional reactions; (3) monetary price, (4) behavioural price and (5) reputation. Focusing on restaurants, Kwun (2004) identified three components of value: brand, price and risk.

\section{Golf tourism satisfaction studies}

Despite the relevance of golf as a tourism activity, the literature on golf tourists' satisfaction is rather limited. One of the earliest studies (Petrick, Backman, \& Bixler, 1999) examined the determinants of golf course satisfaction across different types of golf courses. Three years later, Petrick and colleagues (Petrick, 2002a; 2002b; Petrick \& Backman, 2002) continued to explore the factors influencing golf tourists' satisfaction. These studies have examined whether novelty (Petrick, 2002b), experience use history (Petrick, 2002a) and attribute and information satisfaction (Petrick \& Backman, 2002) were related to golf travellers' satisfaction. More contemporary work has focused on golf attributes (Krohn, 2008; Hutchinson, Wang, \& Lai, 2010), emotions (Hutchinson et al., 2010) and service quality and value (Hennessey, Macdonald, \& MacEachern, 2008; Hutchinson et al., 2009; Moital \& Dias, 2012). These studies, which are of a quantitative nature, have assessed the relationship between satisfaction and its predictors through a range of statistical methods, including ANOVA (Petrick, 2002a), standard (Petrick, 2002b) and stepwise (Petrick \& Backman, 2002) multiple regression and more recently, structural equation modelling (Hutchinson et al., 2009; Hutchinson et al., 2010). With the exception of Moital and Dias (2012), who compared hard-core and recreational golf-tourists, what these studies have failed to do is to examine the determinants of satisfaction across different types of golf tourists, including across countries of origin. The next section reviews research on the relationship between culture and satisfaction. 


\section{Country of origin and satisfaction}

One important characteristic of tourism products is that they are invariably consumed by tourists from a myriad of countries. The examination of the extent to which country of origin influences tourist behaviour, including tourist satisfaction, has received some attention in the tourism literature. The argument behind the study of how the country of origin influences the consumption of tourism products lies in the assumption that nations have distinct cultural characteristics that result in unique expectations (Kaufman-Scarborough, 2000). These cultural characteristics manifest themselves in the form of, for example, cultural norms, which serve as a basis in the formation of expectations (Weiemaier, 2000). Several authors have researched the relationship between the country of origin and tourist satisfaction (for a detailed review see Kozak, 2001). In general, these studies concluded that tourist satisfaction is influenced by the country of origin to some extent (e.g. Kozak, 2001; Yu \& Goulden, 2006; Tsang \& Ap, 2007). In contrast, other studies found no relationship between country of origin and satisfaction (e.g. Spreng \& Chiou, 2002). No studies were found addressing the relationship between country of origin and satisfaction in the context of golf tourism. Hence, since understanding how such relationship unfolds in the context of golf tourism can contribute to better destination management, this paper sought to examine the extent to which the determinants of satisfaction vary across tourists' country of origin.

\section{METHODOLOGY}

\section{Sample and questionnaire design}

In order to determine which factors influence golf tourist satisfaction, data from the Lisbon Tourism Board's 2008 survey on the profile of golf tourists in Lisbon (Portugal) was used. The sample was stratified based on the number of foreign golf tourists, divided by nationality, which visited Lisbon in 2007. The data was collected through CAPI PDA (Computer Assisted Personal Interviews - Personal Digital Assistant). A total of 521 usable questionnaires were collected, 198 of which were from British nationals, 119 from Nordic tourists (Denmark, Finland, Norway and Sweden) and the remaining 204 were from other countries. For the purposes of this study, a golf tourist is a tourist who has played at least once in one of the golf courses located within the Lisbon Tourism Region.

Tourists were approached around the reception area and/or club house of seven (18-hole) golf courses that are considered as representative of the golf courses in the Lisbon Coast region. The vast majority of golf courses were located in the Estoril Coast/Sintra and Setúbal/Blue Coast areas, thus data was collected at three courses in each of these regions. The seventh course was located in the West (Oeste) region, where there are only a small number of courses. The questionnaire, developed in Portuguese, was translated by qualified translators in to four languages: English, French, Spanish and German. The questionnaire contained 10 variables reflecting the satisfaction with a number of attributes of Lisbon as a golf tourism destination. Five of the factors are related to the quality of golf courses (technical quality, landscape setting, service quality, quality of equipment, ease of booking), one focuses on the quality of accommodation and another on the ease of access to golf courses from where tourists are staying. The remaining three attributes focus on the value of Lisbon as a golfing destination and include the satisfaction with green fees, the cost of playing golf and the price of accommodation. The questionnaire also included a question measuring overall satisfaction with Lisbon as a golfing destination. Both the attributes and overall satisfaction were measured on a scale from 1 to 10 , with one referring to minimum satisfaction and 10 to maximum satisfaction. 
Table 1 shows the demographic and tripographic characteristics for all the respondents, as well as the British and the Nordic golf tourists. Virtually all respondents were over 45 years old, with the sample containing slightly more males than females. Typically, respondents stayed 4 nights in the Estoril Coast or in Setúbal/Blue Coast and played at two golf courses during their stay in Lisbon. No differences were found between British and Nordic golf tourists with regards to demographic and tripographic characteristics, except for age where Nordic tourists tended to be older than British tourists (as given by the higher mean rank).

Table 1. Demographic and tripographic profile of golf tourists (Frequencies, Chi-Square and Mann-Whitney)

\begin{tabular}{|c|c|c|c|c|c|c|c|}
\hline & \multicolumn{2}{|c|}{ All } & \multicolumn{2}{|c|}{ British } & \multicolumn{2}{|c|}{ Nordic } & \multirow{2}{*}{ Mann-Whitney / Chi-Square } \\
\hline & $\mathrm{N}$ & $\%$ & $\mathrm{~N}$ & $\%$ & $\mathrm{~N}$ & $\%$ & \\
\hline \multicolumn{8}{|c|}{ Age } \\
\hline $26-35$ & 4 & 0.8 & 1 & 0.5 & 0 & 0.0 & \multirow{5}{*}{$\begin{array}{c}\text { Mean Rank (British) }=151.53 \\
\text { Mean Rank (Nordic) }=174.05 \\
U=13.626 / / \text { Sig: } 0.018\end{array}$} \\
\hline $36-45$ & 4 & 0.8 & 3 & 1.5 & 0 & 0.0 & \\
\hline $46-55$ & 257 & 49.0 & 107 & 53.8 & 50 & 41.7 & \\
\hline $56-65$ & 44 & .84 & 11 & 5.5 & 11 & 9.2 & \\
\hline+65 & 216 & 41.1 & 77 & 38.7 & 59 & 49.2 & \\
\hline \multicolumn{8}{|c|}{ Gender } \\
\hline Male & 278 & 53.0 & 99 & 49.7 & 68 & 56.7 & $x^{2}=1.436$ \\
\hline Female & 247 & 47.0 & 100 & 50.3 & 52 & 43.3 & $p=0.231$ \\
\hline \multicolumn{8}{|c|}{ Number of nights spent in Lisbon } \\
\hline $1-3$ & 33 & 6.3 & 10 & 5.0 & 7 & 5.8 & \multirow{4}{*}{$\begin{array}{c}\text { Mean Rank (British) }=159.19 \\
\text { Mean Rank (Nordic) }=161.35 \\
\text { U= } 12.101 / / \text { Sig: } 0.758\end{array}$} \\
\hline 4 & 429 & 81.7 & 167 & 83.9 & 97 & 80.8 & \\
\hline 5 & 31 & 5.9 & 11 & 5.5 & 9 & 7.5 & \\
\hline $6+$ & 32 & 6.1 & 11 & 5.5 & 7 & 5.8 & \\
\hline \multicolumn{8}{|c|}{ Staying where? } \\
\hline Estoril Coast & 350 & 66.7 & 137 & 68.8 & 81 & 67.5 & \\
\hline Setúbal/Blue Coast & 137 & 26.1 & 49 & 24.6 & 61 & 28.8 & $x^{2}=0.066$ \\
\hline West (Oeste) & 38 & 7.2 & 13 & 6.5 & 8 & 6.7 & $p=0.968$ \\
\hline \multicolumn{8}{|c|}{ Number of golf courses to be played at } \\
\hline 1 & 44 & 8.7 & 13 & 6.5 & 7 & 5.8 & Mean Rank (British)= 158.65 \\
\hline 2 & 477 & 90.9 & 186 & 93.5 & 111 & 92.5 & Mean Rank (Nordic) $=162.25$ \\
\hline 3 & 4 & 0.8 & 0 & 0.0 & 2 & 1.7 & $U=12.209$ // Sig: 0.4428 \\
\hline
\end{tabular}

\section{Data analysis}

Logistic regression was employed in order to identify the determinants of golf tourists' satisfaction. Logistic regression has been shown to be an effective technique to discriminate between two groups in a marketing research context (Akinci, Kaynak, Atilgan, \& Aksoy, 2007). The objective of logistic regression is to establish the probability of a tourist belonging to one of two variables (the dependent variable) given other variables (the determinants or independent variables) (Field, 2000). In this paper, the dependent variable is global satisfaction. Bearing in mind that logistic regression requires two groups in the dependent variable, golf tourists were classified into 'very satisfied' (answer to the global satisfaction question equal or above 8) and 'moderately satisfied' (answer to the global satisfaction question between 5 and 7 - there were no answer below 5). The determinants or independent variables are the 10 factors that reflect the quality and value of Lisbon as a golf tourism destination. Three regressions were carried out: one for the data as a whole, and one for each of the geographic areas (Britain and Nordic countries).

\section{RESULTS}

Logistic regression works by comparing two models: one that includes only the constant in the regression equation (that is all determinants are omitted) and one that includes the determinants (Field, 2000). These two models are then compared and it is from this comparison that conclusions are made with regards to whether the determinants make a significant contribution to explain the dependent variable. This comparison is made by 
looking at several measures, including the log-likelihood value, the classification accuracy and the Nagelkerke value. If these indicators suggest that the determinants contribute to explain global satisfaction, the contribution of each determinant is then analysed through the $\operatorname{Exp}(ß)$ value (a more detailed explanation of each of these values is provided along with the results).

The characteristics of the three models (all golf tourists, Nordic golf tourists and British golf tourists) are presented in Table 2. An analysis of the log-likelihood values for the initial model (which contains only the constant) and the new model (which contains the 10 determinants) shows a decrease which indicates that the inclusion of the determinants results in fewer unexplained observations. Hence, adding the determinants improves the confidence of the model in correctly classifying golf tourists in terms of whether they are very satisfied or moderately satisfied (Tabachnick \& Fidell, 2001). In other words, the model that contains the determinants is better at predicting to which group a golf tourist belongs to (i.e. if (s)he left moderately or very satisfied).

Table 2 - Characteristics of the models

\begin{tabular}{|c|c|c|c|c|c|c|c|c|c|}
\hline & \multicolumn{3}{|c|}{$\begin{array}{l}\text { All golf tourists } \\
(\mathrm{N}=521)\end{array}$} & \multicolumn{3}{|c|}{$\begin{array}{l}\text { British golf tourists } \\
(\mathrm{N}=196)\end{array}$} & \multicolumn{3}{|c|}{$\begin{array}{l}\text { Nordic golf tourists } \\
(\mathrm{N}=118)\end{array}$} \\
\hline & Value & Df & $p$ & Value & Df & $p$ & Value & Df & $p$ \\
\hline Initial -2 Log likelihood (X2) & 690.987 & & & 254.291 & & & 161.818 & & \\
\hline Final -2 Log likelihood (X2) & 401.254 & & & 140.500 & & & 60.798 & & \\
\hline Nagelkerke $\mathrm{R}^{2}$ & 0.581 & & & 0.606 & & & 0.771 & & \\
\hline Initial classification group & $62.2 \%$ & & & $64.8 \%$ & & & $55.9 \%$ & & \\
\hline Moderately satisfied & $0.0 \%$ & & & $0.0 \%$ & & & $0.0 \%$ & & \\
\hline Very satisfied & $100 \%$ & & & $100 \%$ & & & $100 \%$ & & \\
\hline Final classification group & $81.2 \%$ & & & $82.7 \%$ & & & 85.6 & & \\
\hline Moderately satisfied & $71.1 \%$ & & & $66.7 \%$ & & & 87.9 & & \\
\hline Very satisfied & $87.3 \%$ & & & $91.3 \%$ & & & 85.6 & & \\
\hline Model coefficient $\left(X^{2}\right)$ & 289.734 & 10 & 0.000 & 113.791 & 10 & 0.000 & 101.120 & 10 & 0.000 \\
\hline $\begin{array}{l}\text { Hosmer e Lemeshow's goodness- } \\
\text { of-fit test }\left(X^{2}\right)\end{array}$ & 10.855 & 8 & .210 & 8.655 & 8 & 0.372 & 5.428 & 8 & .711 \\
\hline
\end{tabular}

Another way of analysing the success of the logistic regression model is by looking at the classification accuracy (Tabachnick \& Fidell, 2001). The classification accuracy looks at the ability of the model to correctly predict the global satisfaction category to which a golf tourist belongs to (that is, whether a tourist left very or moderately satisfied) given his/her satisfaction with the quality and value of the golfing destination. In the initial model (with only the constant), the classification accuracy equals the percentage of individuals in the group that contains a higher number of individuals (in this study, the very satisfied tourists). By adding the determinants to the model, it is possible to evaluate the extent to which the classification accuracy improves. The results show that adding the 10 determinants has improved the classification accuracy in the three models (all golf tourists, British and Nordic). The percentages increased from $62.2 \%$ (all tourists), $64.8 \%$ (British tourists) and $55.9 \%$ (Nordic tourists) to above $80 \%$ in all cases.

Nagelkerke's measure, which works as a pseudo $\mathrm{R}^{2}$, can also contribute to understand the extent to which adding determinants improves the model (Tabachnick \& Fidell, 2001). The Nagelkerke's value is usually employed as an approximate measure of explained variance in the dependent variable by the determinants (Field, 2000). As show in Table 2, Nagelkerke's values suggest that the three models are able to explain a good proportion of the variance in golf tourists' global satisfaction with their trip to Lisbon. As far as all golf tourists are concerned, the 10 determinants explain nearly $60 \%$ of the variance in global satisfaction. With regards to the two nationality groups analysed, the 10 determinants explain a greater proportion of the variance in global satisfaction of Nordic tourists $(77 \%)$ than of British 
tourists $(61 \%)$. The value for British tourist can be considered very good, while for Nordic tourists exceptional.

Having established the validity of the three models of golf tourists' satisfaction, the next step involves analysing the parameter estimates for each of the three models (Table 3 ). Two values are presented for each model: $p$ and $\operatorname{Exp}(ß)$. The $p$ value enables the identification of those determinants that make a significant contribution to explain global satisfaction. This paper established a $5 \%$ probability value $(p<0.05)$ to accept a determinant as making a significant contribution. Once the significant determinants are identified, the $\operatorname{Exp}(ß)$ value, also referred to as the odds ratio, is analysed. $\operatorname{Exp}(ß)$ value refers to the probability that a golf tourist is very satisfied if the determinant increases in 1. For example, a $\operatorname{Exp}(ß)$ value of 10 means that an increase in 1 on the satisfaction with a determinant increases 10 times the probability of a tourist to move from the moderately satisfied to the very satisfied camp.

Table 3 - Determinants of satisfaction

\begin{tabular}{lcccccc}
\cline { 2 - 6 } & \multicolumn{2}{c}{ All golf tourists } & \multicolumn{2}{c}{$\begin{array}{c}\text { British golf } \\
\text { tourists }\end{array}$} & \multicolumn{2}{c}{ Nordic golf tourists } \\
\hline Technical quality of golf courses & $\mathrm{p}$ & $\operatorname{Exp}(\beta)$ & $\mathrm{p}$ & $\operatorname{Exp}(ß)$ & $\mathrm{p}$ & $\operatorname{Exp}(ß)$ \\
\hline Landscape setting of golf courses & $.021^{*}$ & 1.492 & .509 & 1.209 & .341 & 1.647 \\
Service quality of golf courses & $.012^{*}$ & 1.732 & $.001^{*}$ & 4.030 & $.024^{*}$ & 4.114 \\
Quality of equipment in golf courses & $.015^{*}$ & 1.350 & .824 & .915 & $.005^{*}$ & 7.374 \\
Ease of booking of golf courses & $.003^{*}$ & 2.047 & $.044^{*}$ & 2.464 & .209 & .366 \\
Cost of playing golf & .080 & 1.505 & $.012^{*}$ & 3.335 & .143 & 2.902 \\
Green fee & $.027^{*}$ & 1.762 & $.046^{*}$ & 2.363 & .161 & 3.024 \\
Access to golf courses from & .067 & 1.616 & .790 & 1.126 & $.004^{*}$ & 8.745 \\
accommodation & .282 & .727 & .112 & .421 & .931 & .936 \\
Quality of accommodation & $.001^{*}$ & 2.587 & $.003^{*}$ & 5.237 & .207 & 2.373 \\
Price of accommodation & .000 & .000 & .000 & .000 & .000 & .000 \\
\hline Constant & & & & & & .867 \\
\hline
\end{tabular}

Legend: * $p<0.05$

The results indicate that six of the 10 determinants contribute to explain global satisfaction of golf tourists (Table 3 ). From these six determinants, according to the $\operatorname{Exp}(ß)$ value, the price of accommodation emerges as the most important determinant (2.6). This value means that an increase in the satisfaction with accommodation price increases 2.6 times the probability of a golf tourist leaving Lisbon very satisfied. In descending order of importance, the other significant determinants are the ease of booking of golf courses $(\operatorname{Exp}(ß)$ of 2$)$, quality of equipment in golf courses $(\operatorname{Exp}(ß)$ of 1.8), green fee $(\operatorname{Exp}(ß)$ of 1.8), landscape setting of golf courses $(\operatorname{Exp}(ß)$ of 1.7) and technical quality of golf courses $(\operatorname{Exp}(ß)$ of 1.5).

With regards to the results across the range of nationalities, the results show that five factors determine the satisfaction of British golf tourists and three of Nordic golf tourists. The perceived performance of the landscape setting of golf courses was a significant determinant for both British and Nordic golf tourists, with similar levels of influence for both groups $(\operatorname{Exp}(ß)$ of just over 4). The other factors that determine the satisfaction of British and Nordic golf tourists are different. For the British, the price of accommodation was found to be most important determinant of global satisfaction $(\operatorname{Exp}(ß)$ of 5.2$)$. Other significant determinants include the quality of equipment in golf courses $(\operatorname{Exp}(ß)$ of 2.5), ease of booking of golf courses $(\operatorname{Exp}(ß)$ of 3.3$)$ and green fee $(\operatorname{Exp}(ß)$ of 2.4). For the Nordic, the most important determinant was the access to golf courses from accommodation $(\operatorname{Exp}(ß)$ of 8.7$)$, followed by the service quality of golf courses $(\operatorname{Exp}(ß)$ of 7.4$)$. In summary, the satisfaction of Nordic golf tourists is determined by fewer and different factors when compared to the British. 


\section{CONCLUSIONS AND RECOMMENDATIONS}

The golf tourism market is highly competitive, with several Southern European and Mediterranean countries striving to attract this lucrative market. In this competitive environment, the objective of any tourist destination should be to make sure as many tourists as possible find their experience highly satisfying. However, even the most competitive destinations are unlikely to highly satisfy all tourists. In this case understanding the reasons behind differential levels of satisfaction can provide destination managers with a basis for taking action aiming at improving those areas that are found to be critical. This paper attempted to address this issue in the context of golf tourism. Using the Lisbon Tourism Board tourist survey, the paper used logistic regression to examine the determinants of golf tourists' satisfaction. Ten attributes of Lisbon as a golfing destination, related to both quality and value, were examined as potential determinants of satisfaction.

The results suggest that increasing levels of satisfaction of golf tourists requires improvements in the performance of a range of factors, both related to quality and value of Lisbon as a golfing destination. At the quality level, the results suggest that improvements in the satisfaction with four areas could lead to greater levels of trip satisfaction: ease of booking of golf courses, quality of equipment in golf courses, landscape setting of golf courses and technical quality of golf courses. Two value related factors were also found to be significant determinants (price of accommodation and green fee).

According to Bowen and Clarke (2002) and Pizam (1999), different cultural backgrounds could result in differentiated perceptions about services, including perceptions of quality and value. Therefore, a second objective of this paper was to examine the extent to which culture influences satisfaction in the context of golf tourism by comparing the determinants of satisfaction across two nationality groups: British and Nordic tourists. The results appear to support the contention that culture influences satisfaction, since the factors that determine the satisfaction of British tourists are fundamentally different of those that determine the satisfaction of Nordic tourists. For example, the satisfaction of British golf tourists appears to be determined by a mix of quality and value factors, while the satisfaction of Nordic golf tourists appears to be determined by quality alone. For British golf tourists, the price of accommodation was the most important determinant, while for the Nordic it was the access to golf courses (highest odds ratios).

\section{Implications for practice and theory}

Monitoring quality and value perceptions is required as an input to marketing decisions. The results of the study have highlighted possible areas of improvement that could lead to higher levels of satisfaction, both at an aggregate level (all nationalities) and at the nationality level. When the strategy of the golfing destination is to enhance the broad levels of satisfaction, the focus should be on improving satisfaction with attributes such as the price of accommodation, ease of booking golf courses and the quality of equipment in the golf course. However, given that destinations usually have country-/region-specific marketing strategies, they should consider the specific characteristics of each nationality when designing these strategies. The results have shown that improvements which were found to be important for the whole sample were not necessarily important for a specific nationality group. For example, the price of accommodation was found to be a determinant for the British, but not for the Nordic golf tourists. Hence, if golfing destinations aim to improve the satisfaction levels of the Nordic, they will have to look at other areas of the golf product other than the price of accommodation. 
The need to look beyond the general patterns in the data is perhaps more evident when attributes found not to be relevant when the whole sample of golf tourists is considered, were found to be important determinants for specific nationalities. In this study there were two such cases: access to golf courses and service quality of golf courses. If only a broad analysis had been carried out, the obvious marketing implication would be that these two areas should not be a priority. However, the analysis by nationality not only clearly identified these two attributes as critical influences on the overall satisfaction of the Nordic golf tourists, but also that these were the two most important determinants (highest odds ratio). Therefore, it is clear that interventions to enhance satisfaction with the access to, and service quality of golf courses directed at an important market such as Nordic golf tourists are justified.

Conceptually, the results of this paper challenge the validity of running statistical analysis using whole samples as the results could be misleading with regards to the critical influences on satisfaction. Exploring the data across groups within important segmentation variables, such as nationality, is recommended as it can identify relevant determinants for some of the groups. The identification of relevant determinants of satisfaction for individual segments will provide valuable marketing intelligence which can then be used in developing effective marketing strategies for specific segments.

\section{Limitations and further research}

This study contains several limitations that lead to opportunities for further research. Although the Nagelkerke values and the classification accuracies suggest that the 10 attributes (determinants) explain a good proportion of the variance in global satisfaction, future studies could consider a more extensive set of value/service attributes. Besides attributes, other variables could also be included in the model, such as trip features and personal characteristics of the golf tourist. These include independent vs. organised trip, first time vs. repeat visitor and handicap. Unlike linear regression, logistic regression can accommodate categorical variables such as the ones just mentioned.

Due to the low number of tourists from other nationalities, the analysis was restricted to British and Nordic nationals. Larger samples of golf tourists will enable comparing a more diverse set of countries that are also important demand markets for golf tourism (e.g. Benelux and Germany). Finally, studying golf tourism satisfaction could be complemented by a more qualitative type study, so that the reasons behind satisfaction can be researched and understood in greater depth. Qualitative studies could help understanding more about the satisfaction with each of the quality/value factors that were found to be important determinants in this paper. For example, interviewing a sample of moderately satisfied tourists could help understanding the reasons behind satisfaction with the green fee.

\section{ACKNOWLEDGMENTS}

The work for this paper was carried out as part of a grant under the The Sport Tourism Opportunities for Research, Mobility and International Networking Group (STORMING) Initiative, funded by the ESRC UK (Economic and Social Research Council, United Kingdom). The authors would like to thank ATL (Lisbon Tourism Board) the access to the database that was used for the empirical study. 


\section{REFERENCES}

Akama, J.S., \& Kieti, D.M. (2003). Measuring tourist satisfaction with Kenya's wildlife safari: A case study of Tsavo West National Park. Tourism Management, 24(1), 73-81.

Akinci, S., Kaynak, E., Atilgan, E., \& Aksoy, Ş. (2007). Where does the logistic regression analysis stand in marketing literature? A comparison of the market positioning of prominent marketing journals. European Journal of Marketing, 41(5/6), 537-567.

Baker, D., \& Crompton, J. (2000). Quality, satisfaction and behavioral intentions. Annals of Tourism Research, Vol. 27, 785-804.

Boukas, N., \& Ziakas, V. (2012). Impacts of the Global Economic Crisis on Cyprus Tourism and Policy Responses. International Journal of Tourism Research, doi: 10.1002/jtr.1878.

Bowen, D., \& Clarke, J. (2002). Reflections on tourist satisfaction research: Past, present and future. Journal of Vacation Marketing , 8(4), 297-308.

Bradley, G. L., \& Sparks, B. (2012). Antecedents and Consequences of Consumer Value: A Longitudinal Study of Timeshare Owners. Journal of Travel Research, 51(2), 191-204.

Chand, M. (2010). Measuring the service quality of Indian tourism destinations: an application of SERVQUAL model. International Journal of Services Technology and Management, 13(3-4), 218-233.

Chen, C.F.,\& Chen, F.S. (2010). Experience Quality, Perceived Value, Satisfaction and Behavioral Intentions for Heritage Tourists. Tourism Management. 31(1), 29-35.

Crompton, J. (2003). Adapting Herzberg: A Conceptualization of the Effects of Hygiene and Motivator Attributes on Perceptions of Event Quality. Journal of Travel Research, 41, 305310.

Field, A. (2000). Discovering statistics. Using SPSS for Windows: Advanced techniques for beginners. London: Sage.

Garau-Vadell, J.B., \& Borja-Sole, L. (2008). Golf in mass tourism destinations facing seasonality: a longitudinal study. Tourism Review , 63(2), 16-24.

Hennessey, S., Macdonald, R., \& MacEachern, M. (2008). A framework for understanding golfing visitors to a destination. Journal of Sport \& Tourism, 13 (1), 5-35.

Holbrook, M. (1999). Introduction to consumer value. In: M. Holbrook (Ed.), Consumer Value: A Framework for Analysis and Research (pp. 1-28). New York, NY:Routledge.

Hutchinson, J., Lai, F., \& Wang, Y. (2009). Understanding the relationships of quality, value, equity, satisfaction, and behavioral intentions among golf travelers. Tourism Management, 30(2), 298-308.

Hutchinson, J., Wang, Y., \& Lai, F. (2010). The impact of satisfaction judgment on behavioral intentions: an investigation of golf travelers. Journal of Vacation Marketing, vol. 16, no. 1, 4559. 
Kaufman-Scarborough, C. (2000). Asian-American consumers as a unique market segment: fact or fallacy? Journal of Consumer Marketing, 17, 249-262.

Kim, S.S., \& Lee, C.K. (2002). Push and pull relationships. Annals of Tourism Research, 29(1), 257-260.

Knutson, B. J., Stevens, P., \& Patton, M. (1995). DINESERV: Measuring service quality in quick service, casual/theme and fine dine restaurants. Journal of Hospitality and Leisure Marketing, 3(2), 35-44.

Kouthouris, C., Alexandris, K. (2005). Can service quality predict customer satisfaction and behavioral intentions in the sport tourism industry? An application of the SERVQUAL model in an outdoors setting, Journal of Sport Tourism, Vol. 10, No.2, 101-111.

Kozak, M. (2001). Comparative assessment of tourist satisfaction with destinations across two nationalities. Tourism Management, 2, 391- 401.

Kozak, M., \& Rimmington, M. (2000). Tourist satisfaction with Mallorca, Spain, as an offseason holiday destination. Journal of Travel Research, 38 (3), 260-269.

Krohn, B. D. (2008). The influence of attribute performance appraisal, emotion and time on the satisfaction response of golf travellers, Unpublished PhD thesis. USA: Graduate School of Clemson University.

Kwun, J. - W. (2004). Effects of brand, price and risk on customers' value perceptions and behavioural intentions in the restaurant industry. Journal of Hospitality \& Leisure Marketing, 11(1), 31-49.

Ladhari, R. (2009). Service quality, emotional satisfaction, and behavioural intentions: A study in the hotel industry. Managing Service Quality, 19(3), 308-331.

Lee, S. Y., Petrick, J.F., \& Crompton, J. (2007). The roles of quality and intermediary constructs in determining festival attendees' behavioral intention. Journal of Travel Research, 45(4), 402-412.

Lisbon Tourism Board (n/d). Informação sobre turismo de golfe. Email communication (29 September 2009).

MINTEL (2006). Golf Tourism - International. Retrieved May 12, 2006 from http://reports.mintel.com/.

Moital, M., \& Dias, N. R. (2012). Golf Tourists' Satisfaction: Hard-core versus Recreational Golf Tourists, In: Shipway, R. \& Fyall, A. (eds). International Sport Events: Impacts, Experience and Identities, Abingdon, Routledge, pp. 127-140.

Nam, J., Ekinci, Y., \& Whyatt, G. (2011). Brand Equity, Brand Loyalty and Consumer Satisfaction. Annals of Tourism Research, 38(3), 1009-1030.

Netconsumo.com (2011, February 28), Turistas gastam 123 euros por dia a visitar a capital, Retrieved October 10, 2012 from http://www.netconsumo.com/.

Oh, H., Fiore, A., \& Jeoung, M. (2007), Measuring Experience Economy Concepts: Tourism Applications. Journal of Travel Research, 46(2), 119-132. 
Oliver, R.L. (1997). Satisfaction: A Behavioral Perspective on the Consumer. New York: Irwin/MaGraw-Hill.

Oliver, R. L., \& Swan, J. E. (1989). Consumer perceptions of interpersonal equity and satisfaction in transactions: A field survey approach. Journal of Marketing, 53, 21-35.

Parasuraman, A., Zeithaml, V., \& Berry, L. (1990). Developing Quality Service: Balancing Customer Perceptions and Expectations. New York: The Free Press.

Petrick, J.F. (2002a). Experience use history as a segmentation tool to examine golf travellers' satisfaction, perceived value and repurchase intentions. Journal of Vacation Marketing, 8(4), 332-342.

Petrick, J.F. (2002b). An examination of golf vacationers' novelty. Annals of Tourism Research, 29(2), 384-400.

Petrick, J.F., \& Backman, S.J. (2002). An examination of the determinants of golf travelers' satisfaction. Journal of Travel Research, 40, 252-258.

Petrick, J. F., Morais, D. D., \& Norman, W. C. (2001). An examination of the determinants of entertainment vacationers' intentions to revisit. Journal of Travel Research, 40, 41-48.

Petrick, J. F, Backman S. J. \& Bixler, R. D. (1999). An investigation of selected factors' impact on golfer satisfaction and perceived value. Journal of Park and Recreation Administration, 17 (1), 40-59.

Pizam, A. (1999). Cross-cultural tourist behavior. In A. Pizam \& Y. Mansfeld (Eds.), Consumer behavior in travel and tourism (pp.393-411). Binghamton, NY: The Haworth Press, Inc.

Portuguese Golf Federation (n.d.). Oferta de Campos de Golfe em Portugal. Email communication (16 September 2009).

Portuguese Tourism Board (2007). Plano Estratégico Nacional do Turismo. Retrieved February 26, 2007 from http://www.turismodeportugal.pt/

Prayag, G., \& Ryan, R. (2012). Antecedents of Tourists' Loyalty to Mauritius: The Role and Influence of Destination Image, Place Attachment, Personal Involvement, and Satisfaction. Journal of Travel Research, 51(3), 342-356.

Sánchez, J., Callarisa, L., Rodríguez, R. M., \& Moliner, M. A. (2006). Perceived value of the purchase of a tourism product. Tourism Management, 27, 394-409.

Schmallegger, D., Taylor, A., \& Carson, D. (2011). Rejuvenating outback tourism through market diversification: the case of the Flinders Ranges in South Australia. International Journal of Tourism Research, 13, 384-399.

Song, H., R., van der Veen, R., Li, G., \& Chen, J. (2012). The Hong Kong Tourist Satisfaction Index. Annals of Tourism Research, Volume 39, Issue 3, 459-479.

Spreng, R., \& Chiou, J. (2002). A cross-cultural assessment of the satisfaction formation process. European Journal of Marketing, 36 (7/8), 1-8. 
Szymanski, D.M., \& Henard, D.H. (2001). Customer satisfaction: a meta-analysis of the empirical

evidence. Journal of the Academy Marketing Science, Vol. 29 No.1, 16-35.

Tabachnick, B.G., \& Fidell, L.S. (2001). Using Multivariate Statistics. Boston: Allyn and Bacon.

Tsang, N., \& Ap, J. (2007). Tourists' Perceptions of Relational Quality Service Attributes: A Cross-Cultural Study. Journal of Travel Research, 45 (February), 355-363.

Tse, D. K., \& Wilton, P. C. (1988). Models of consumer satisfaction: an extension. Journal of Marketing Research, 25, 204-212.

Vermeulen, I.E., \& Seegers, D. (2009). Tried and tested: The impact of online hotel reviews on consumer consideration. Tourism Management, 30, 123-127.

Weiermaier, K. (2000). Tourists' Perceptions towards and satisfaction with service quality in the cross-cultural service encounter: implications for hospitality and tourism management. Managing Service Quality, 10(6), 397-409.

Williams, P., \& Soutar, G.N. (2009). Value satisfaction and behavioral intentions in an adventure tourism context. Annals of Tourism Research, 36(3), 413-438.

Woodall, T. (2003). Conceptualising 'value for the customer': An attributional, structural and dispositional analysis. Academy of Marketing Science Review, 12, 1-42.

Yoon, Y., \& Uysal, M. (2005). An examination of the effects of motivation and satisfaction on destination loyalty: a structural model. Tourism Management, 26, 45-56.

Yu, L., \& Goulden, M.A. (2006). A comparative analysis of international tourist's satisfaction in Mongolia. Tourism Management, 27(6), 1331-1342.

Zehrer, A., Crotts, J.C., \& Magnini, V.P. (2011). The perceived usefulness of blog postings: An extension of the expectancy-disconfirmation paradigm. Tourism Management, 31(1), 106-113.

Zeithaml, V. A. (1988). Consumer perceptions of price, quality, and value: a means-end model and synthesis of evidence. Journal of Marketing, 52, 2-22. 